DOI: https://doi.org/10.15407/kvt201.03.033

UDC 681.5

ZHITECKII L.S. ${ }^{1}, \mathrm{PhD}$ (Engineering),

Acting Head of the Intelligent Automatic Systems Department e-mail: leonid_zhiteckii@i.ua

AZARSKOV $\overline{\mathbf{V}} \cdot \mathbf{N}^{2}$, DSc (Engineering), Professor,

Head of the Aerospace Control Systems Department, e-mail: azarskov@nau.edu.ua

SUSHCHENKO O.A. ${ }^{2}$, DSc (Engineering), Professor, Professor of the Aerospace Control Systems Department, e-mail: sushoa@ukr.net

YANOVSKY F.J. ${ }^{2}$, DSc (Engineering), Professor,

Head of the Department of Electronics, Robotics, Monitoring

and IoT Technologies

e-mail: yanovsky@nau.edu.ua

SOLOVCHUK K.Yu. ${ }^{3}$,

Senior Lecturer at the Higher and Applied Mathematics Department

e-mail: solovchuk_ok@ukr.net

${ }^{1}$ International Research and Training Center for Information Technologies

and Systems of the National Academy of Sciences of Ukraine

and Ministry of Education and Science of Ukraine, Kyiv, Ukraine,

40, Acad. Glushkov av., Kyiv, 03187, Ukraine

${ }^{2}$ National Aviation University, Kyiv, Ukraine.

1, Lubomyra Husara av., Kyiv, 03680, Ukraine

${ }^{3}$ National University «Yuri Kondratyuk Poltava Polytechnic»

24, Pershotravnevyj av., Poltava, 36011, Ukraine

\title{
CONTROL OF A NONSQUARE MULTIVARIABLE SYSTEM USING PSEUDOINVERSE MODEL-BASED STATIC OUTPUT FEEDBACK
}

Introduction. The paper deals with nonzero set-point regulating the first-order linear discrete-time multivariable system. The case where the number of outputs exceeds the number of control inputs is considered. It is assumed that arbitrary but bounded unmeasurable disturbances are present. The assumption that the elements of the matricies arising in the system equation are unknown. However, their bounds are assumed to be known a priori. From practical point of view, it is important to design a simple controller similar to reduced-order or static output feedback (SOF) controllers. A difficulty associated with this problem is in establishing the existence of SOF control to be able to cope with a given system. The three different problems concerning the optimality, ultimate boundedness and robustness features are stated and solved.

The purpose of the paper is to answer the question: is there the SOF control based on the pseudoinverse concept to stabilize some first-order multivariable system with nonsquare gain matrix? 
Methods. The methods based on the theory of matricies are utilized.

Results. The pseudoinverse model-based control leading to static output feedback is proposed to reject unmeasured disturbances. The optimality and robustness properties of such controller are established. Numerical examples and simulation results are presented to support theoretical study.

Conclusion. The paper shed some light on the existence of the pseudoinverse static output feedback controllers which can either be optimal (in the absence of any uncertainty) or be robust stable against parameter uncertainties dealing with the linear multivariable firstorder discrete-time system in a hard case when its gain matrix is nonsquare (in contrast to the known results).

Keywords: discrete time, feedback control methods, pseudoinversion, multivariable control systems, robustness.

\section{INTRODUCTION}

A problem of an efficient control of multivariable systems in the presence of unmeasurable disturbances stated three decades ago in [1] remains a topic of meticulous attention of many researches until recently. Their results have been reported in numerous papers and generalized in several books [2-5] et al.

To reject arbitrary bounded disturbances, the so-called inverse model concept has been proposed by several authors. Since the beginning of the $21^{\text {st }}$ century, a significant progress has been achieved utilizing this concept $[6,7]$ and other works. Most these works except [7] dealt with continuous-time multivariable systems. However, this approach is quite unacceptable if the systems to be controlled are either ill-conditioned or nonsquare. Some researches observed that the inverse-based controller may be also not feasible for designing some process control systems containing ill-conditioned plants since they may become (almost) noninvertible in the presence of uncertainties [8]. Also, there exist certain difficulties in order to achieve a perfect control performance in the case where the number of the plant outputs exceeds the number of its control inputs. Similar problem falling into this category is the development of the automatic control system for an artificial heart having three outputs and two control inputs [9].

It turned out that the so-called Moore-Penrose inverse (pseudoinverse) modelbased approach can be exploited to cope with the noninvertibility of singular square and any nonsquare systems. This approach has theoretically been substantiated in the papers [10-12] which dealt with problems of rejecting any bounded disturbances for a wide class of discrete-time multivariable noninvertible memoryless systems.

From practical point of view, it is important to design a simple controller similar to reduced-order or static output feedback (SOF) controllers. A difficulty associated with this problem is in establishing the existence of SOF control to be able to cope with a given plant [13-15]. Nevertheless, it turns out that in the case of the first-order multivariable system, the pseudoinverse model-based approach leads straight to SOF control.

In last years, various constructive approaches applicable to linear continuous-time and discrete-time systems with possible uncertainties have been advanced for establishing conditions under which SOF controllers can exist. Also, different numerical algorithms for designing these controllers have been proposed in [16-22] et al. Among them, the authors of [16] have obtained some attractive SOF solvability conditions derived from structural properties of the 
open-loop discrete-time systems. Within the framework of these conditions, they studied the case where there were more outputs than control inputs. Now, the question that we need to answer is as follows: is there the SOF control based on the pseudoinverse concept to stabilize some first-order multivariable system with nonsquare gain matrix?

The paper extends the ideas of [10-12] to nonzero set-point regulating nonsquare discrete-time first-order system in which the number of outputs exceeds the number of its control inputs. The main effort is focused on deriving conditions under which the optimality, ultimate boundedness and also robustness properties of resulting closed-loop control system can be achieved.

The purpose of the paper is to answer the question: is there the SOF control based on the pseudoinverse concept to stabilize some first-order multivariable system with nonsquare gain matrix?

\section{PROBLEM FORMULATION}

Consider a linear first-order multivariable discrete-time time-invariant system described by the autoregressive moving average exogenous (ARMAX) model of the simplest form

$$
y_{n+1}=A y_{n}+B u_{n}+v_{n+1} \text {, }
$$

where $y_{n} \in \mathbf{R}^{m}, u_{n} \in \mathbf{R}^{r}$ and $v_{n} \in \mathbf{R}^{m}$ represent the measured output, control input and the unmeasurable disturbance vectors, respectively. $A \in \mathbf{R}^{m \times m}$ and $B \in \mathbf{R}^{m \times r}$ are the fixed square and nonsquare matrices, respectively, given as

$$
A=\left(\begin{array}{ccc}
a^{(11)} & \ldots & a^{(1 m)} \\
\cdot & \cdot & \cdot \\
a^{(m 1)} & \ldots & a^{(m m)}
\end{array}\right) \text { and } B=\left(\begin{array}{ccc}
b^{(11)} & \ldots & b^{(1 r)} \\
\cdot & \cdot & \cdot \\
b^{(m 1)} & \ldots & b^{(m r)}
\end{array}\right) \text {. }
$$

Let

$$
r<m
$$

mean that the number of control inputs is less than the number of system outputs.

The following assumptions are made.

A1. The elements $a^{(i j)}$ and $b^{(i j)}$ of $A$ and $B$ having the form (2) may be unknown. However, the bounds

$$
\begin{gathered}
a_{\min }^{(i j)} \leq a^{(i j)} \leq a_{\max }^{(i j)}, \quad(i=1, \ldots, m, j=1, \ldots, m), \\
b_{\min }^{(i j)} \leq b^{(i j)} \leq b_{\max }^{(i j)}, \quad(i=1, \ldots, m, j=1, \ldots, r)
\end{gathered}
$$

on these elements are known a priori.

A2. The each component of $v_{n}$ is an arbitrary, but bounded in modulus variable satisfying

$$
\left\|v_{n}\right\| \leq\|v\|_{\infty}<\infty \quad \forall n=1,2, \ldots
$$


where the well-known definition $\|z\|_{\infty}:=\sup _{0 \leq n<\infty}\left\|z_{n}\right\|$ of the so-called $\ell_{1}$-norm of any bounded sequence $\left\{z_{n}\right\}$ denoted as $\|z\|_{\infty}$ is used.

A3. $\left\{y_{n}^{0}\right\}$ is a bounded nonzero set-point vector sequence such that the desired $y_{n+1}^{0}$ is always known at each $n$th time instant implying $\left\|y_{n}^{0}\right\| \not \equiv 0 \quad(n=1,2, \ldots)$ and $\left\|y^{0}\right\|_{\infty}<\infty$. Without loss of generality, it is supposed that each component of $y_{n}^{0}$ may remain constant over a time (finite or infinite).

Defining the output error vector

$$
e_{n}=y_{n}^{0}-y_{n},
$$

introduce the local control performance index

$$
J_{n}=\sup _{v_{n}:\left\|v_{n}\right\|_{2} \leq \varepsilon}\left\|e_{n}\right\|_{2}
$$

where $\|z\|_{2}$ denotes the Euclidean norm (2-norm) of a vector $z$. This criterion evaluates the capability of a controller to rejecting the bounded disturbances at the $n$th time instant in the worst case.

The following three problems are stated and solved.

Problem 1. Suppose matrices $A$ and $B$ are known. Noting that $J_{n}$ of the form (8) depends only on one past $u_{n-1}$ (due to (7) together with (1)), devise the optimal control which minimizes $J_{n+1}$ with respect to all possible bounded $u_{n}$ s at the $n$th time instant producing

$$
J_{n+1} \rightarrow \inf _{u_{n} \in \mathbf{R}^{r}} .
$$

Problem 2. Setting $A$ and $B$ be known, establish conditions guaranteeing the ultimate boundedness of outputs and control inputs in the form

$$
\underset{n \rightarrow \infty}{\limsup }\left\|y_{n}\right\|<\infty, \quad \limsup _{n \rightarrow \infty}\left\|u_{n}\right\|<\infty .
$$

Problem 3. Subject to Assumptions A1-A3, devise the control law under which the requirements (10) will be satisfied for any $A$ and $B$ with the elements given by the interval constraints (4) and (5), respectively, i.e., the robustness of controller will be achieved.

\section{A PRELIMINARY}

Consider the system (1) with no uncertainties with respect to the matrices $A$ and $B$. Moreover, let (for the time being) $B$ be a nonsingular $r \times r$ matrix implying that $r=m$ (instead of (3)). Choose the control law

$$
u_{n}=B^{-1} y_{n+1}^{0}-B^{-1} A y_{n}
$$


in which $B^{-1}$ denotes the inverse of $B$, to produce $e_{n+1}=-v_{n+1}$ $\left(\left\|e_{n+1}\right\|=\left\|v_{n+1}\right\|\right)$. This causes

$$
\left\|e_{n+1}\right\| \leq\|v\|_{\infty}, \quad n=0,1,2, \ldots
$$

It can simply be shown that the controller defined in (11), which may be called the inverse model-based controller, is optimal (in the sense of (9)). Actually, any other control law may give $\left\|e_{n+1}\right\|_{2}>\|v\|_{\infty}$ (instead of (12)) if certain $v_{n}$ satisfying $(6)$ is present at $(n+1)$ th time instant.

At first sight, it seems that if $B$ is noninvertible then $B^{-1}$ might be replaced by the Moore-Penrose inverse matrix $B^{+}$defined by the formula in [23, Theorem 3.4]

$$
B^{+}=\lim _{\delta \rightarrow 0}\left(B^{\mathrm{T}} B+\delta^{2} I_{r}\right)^{-1} B^{\mathrm{T}}
$$

to design the control law

$$
u_{n}=B^{+} y_{n+1}^{0}-B^{+} A y_{n} .
$$

Nevertheless, such a possibility remains without strict substantiations for the time being since both the optimality of (14) and the stability of the closedloop control system (1) exploiting (14) are not guaranteed as yet. Next section sheds some light on this possibility.

\section{OPTIMAL STABLE CONTROL DESIGN}

In this section, Problems 1 and 2 are solved. Namely, the optimality and the stability (the ultimate boundedness) of the closed-loop control system containing the plant (1) and the controller (14) are established in the following theorem.

Theorem 1. Subject to (3), and Assumptions (A2) and (A3), if the control law (14) is applied to the system (1), then:

a) the optimality properties of the closed-loop control system (1), (14) defined in (9) is ensured with

$$
J_{n+1} \leq\left\|\left(I_{m}-B B^{+}\right)\left(y_{n+1}^{0}-A y_{n}\right)\right\|_{2}+\varepsilon,
$$

where

$$
\varepsilon:=\sup \left\|v_{n}\right\|_{2}
$$

and $I_{N}$ denotes the $N \times N$ identity matrix;

b) the ultimate boundedness of $\left\{\left\|y_{n}\right\|\right\}$ caused by (14) is guaranteed if

$$
q<1
$$

with

$$
q=\left\|\left(I_{m}-B B^{+}\right) A\right\|,
$$

where $\|P\|$ denotes any norm of some matrix $P$; 
c) under conditions (17) together with (18), the sequence $\left\{\left\|u_{n}\right\|\right\}$ remains bounded.

Proof. a) Using (1) together with (7), one has $e_{n+1}=y_{n+1}^{0}-A y_{n}-B u_{n}-v_{n+1}$ which causes

$$
\left\|e_{n+1}\right\|_{2} \leq\left\|y_{n+1}^{0}-A y_{n}-B u_{n}\right\|_{2}+\left\|v_{n+1}\right\|_{2} \text {. }
$$

Since the sequence $\left\{v_{n}\right\}$ does not depend on $\left\{y_{n}\right\}$, due to (6), (8) and (16), the inequality (19) yields

$$
J_{n+1} \leq\left\|y_{n+1}^{0}-A y_{n}-B u_{n}\right\|_{2}+\varepsilon
$$

giving

$$
\inf _{u_{n} \in \mathbf{R}^{r}} J_{n+1} \leq \inf _{u_{n} \in \mathbf{R}^{r}}\left\|\left[y_{n+1}^{0}-A y_{n}\right]-B u_{n}\right\|_{2}+\varepsilon .
$$

Further, utilizing Theorem 3.4 of [23], it can be concluded that there exists a vector $u_{n}$ satisfying

$$
\left\|\left[y_{n+1}^{0}-A y_{n}\right]-B u_{n}\right\|_{2}=\inf _{\chi: \mathbf{R}^{m} \times \mathbf{R}^{m} \rightarrow \mathbf{R}^{r}}\left\|\left[y_{n+1}^{0}-A y_{n}\right]-B \chi\left(y^{0}, y_{n}\right)\right\|_{2}
$$

with any vector-valued operator $\chi$. By virtue of (21), this vector is determined as $u_{n}=B^{+}\left[y_{n+1}^{0}-A y_{n}\right]$ leading directly to the pseudoinverse control of the form (14). Comparing (21) with (20), one can argue that such control is optimal since it minimizes the upper bound on $J_{n+1}$ among all possible $\chi(\cdot, \cdot)$ mapping the pair $\left(y^{0}, y_{n}\right)$ onto $u_{n}$. Substituting (14) into the right-hand side of (20) gives this upper bound in the explicit form represented by (15). This establishes statement a).

b) Substituting (14) into (1), one gets

$$
y_{n+1}=B B^{+} y_{n+1}^{0}+\left(I_{m}-B B^{+}\right) A y_{n}+v_{n+1} .
$$

By virtue of (6), this equation produces

$$
\left\|y_{n+1}\right\| \leq\left\|B B^{+}\right\|\left\|y^{0}\right\|_{\infty}+\left\|\left(I_{m}-B B^{+}\right) A\right\|\left\|y_{n}\right\|+\|v\|_{\infty},
$$

where the well-known properties $\left\|P_{1} P_{2} z\right\| \leq\left\|P_{1} P_{2}\right\|\|z\| \quad$ and $\left\|z_{1}+z_{2}\right\| \leq\left\|z_{1}\right\|++\left\|z_{2}\right\|$ of the norm of any matrices $P_{1}, P_{2}$ and of any vectors $z, z_{1}, z_{2}$ have been utilized.

Using (18), we may rewrite (22) as follows:

$$
\left\|y_{n}\right\| \leq\left\|B B^{+} y^{0}\right\|+q\left\|y_{n-1}\right\|+\|v\|_{\infty} .
$$

Iterating (23), we obtain 


$$
\begin{aligned}
& \left\|y_{n+1}\right\| \leq\left\|B B^{+}\right\|\left\|y^{0}\right\|_{\infty}+q\left\|y_{n}\right\|+\|v\|_{\infty} \\
& \quad \leq(1+q)\left\|B B^{+}\right\|\left\|y^{0}\right\|_{\infty}+q^{2}\left\|y_{n-1}\right\|+(1+q)\|v\|_{\infty} \leq \ldots \\
& \quad \leq\left(1+q+q^{2}+\ldots+q^{n-1}\right)\left(\left\|B B^{+}\right\|\left\|y^{0}\right\|_{\infty}+\|v\|_{\infty}\right)+q^{n}\left\|y_{0}\right\| .
\end{aligned}
$$

These inequalities give that if (17) is satisfied, then

$$
\limsup _{n \rightarrow \infty}\left\|y_{n}\right\| \leq \frac{1}{1-q}\left(\left\|B B^{+}\right\|\left\|y^{0}\right\|_{\infty}+\|v\|_{\infty}\right)<\infty .
$$

This fact proves statement $b$ ).

c) Since $\left\{\left\|y_{n}\right\|\right\}$ is shown to be bounded, from (14), the validity of this statement follows immediately.

Corollary. Let

$$
\|A\|_{2}<1
$$

where $\|A\|_{2}$ denotes the spectral norm of $A$ given by

$$
\|A\|_{2}=\max _{i=1, \ldots, m} \lambda_{i}\left(A^{\mathrm{T}} A\right)
$$

and where $\lambda_{i}(\cdot)$ represents the $i$ th eigen-value of $A^{\mathrm{T}} A$. Then, with the requirement (17), the boundedness properties given in statements b) and c) of Theorem 1 are guaranteed.

Proof. According to [23, Exercise 3.7.6], it can be established that $\left\|I_{m}-B B^{+}\right\|_{2}=1$. This yields

$$
q=\left\|\left(I_{m}-B B^{+}\right) A\right\|_{2} \leq\left\|I_{m}-B B^{+}\right\|_{2}\|A\|_{2} \leq\|A\|_{2} .
$$

Due to (24), the last inequality of (25) leads to the condition (17) of Theorem 1 proving the result.

Remark 1. Note that, the condition

$$
\operatorname{rank} B=r \text {, }
$$

implying that $B$ has the full rank, is not necessary.

Remark 2. If rank $B$ satisfies (26), then instead of (13), the simple formula $B^{+}=\left(B^{\mathrm{T}} B\right)^{-1} B^{\mathrm{T}}$ taken, e.g., from [23, Exercise 3.5.3] may be used to calculate $B^{+}$.

Remark 3. The condition (24) means that the open-loop control system (1) is asymptotically stable since

holds producing

$$
\max _{i=1, . ., m}\left|\lambda_{i}(A)\right| \leq\|A\|_{2}
$$

$$
\max _{i=1, \ldots, m}\left|\lambda_{i}(A)\right|<1
$$

In this case, $A$ is said to be the Schur stable matrix. 


\section{AN OBSERVATION}

It turns out that the asymptotic stability of (1) is not necessary to ensure $q<1$.

To illustrate this fact that is not obvious, the following numerical example will be considered.

Example 1. Let

$$
A=\left(\begin{array}{lll}
-0.35 & -0.35 & -0.35 \\
-0.20 & -1.00 & -0.30 \\
-0.20 & -0.20 & -0.50
\end{array}\right), \quad B=\left(\begin{array}{rr}
1.2 & 0.1 \\
-0.6 & 0.9 \\
0.6 & 2.1
\end{array}\right)
$$

In this case, $\operatorname{rank} B=2$, and $\max _{i=1, \ldots, m}\left|\lambda_{i}(A)\right| \approx 1.24>1$ whereas $\|A\|_{1}:=\max _{j \in[1, r]} \sum_{i=1}^{m}\left|a^{(i j)}\right|=1.55$, where $\|P\|_{1}$ denotes the column norm of $P$. This implies that equation (1) describes the unstable system. Nevertheless, the calculation of $q$ by (18) gives $q=\left\|\left(I_{m}-B B^{+}\right) A\right\|_{1} \approx 0.9<1$. Hence, the requirement (17) may be satisfied while the plant is actually unstable.

\section{ROBUSTNESS ANALYSIS}

In the case of parameter uncertainty given by (4) and (5), we propose replacing the control law (14) by

$$
u_{n}=B_{0}^{+} y_{n+1}^{0}-B_{0}^{+} A_{0} y_{n}
$$

with some fixed matrices $A_{0}=\left(a_{0}^{(i j)}\right)_{m \times m}$ and $B_{0}=\left(b_{0}^{(i j)}\right)_{m \times r}$. Their elements are chosen as $a_{0}^{(i j)} \in\left[a_{\min }^{(i j)}, a_{\max }^{(i j)}\right]$ and $b_{0}^{(i j)} \in\left[b_{\min }^{(i j)}, b_{\max }^{(i j)}\right]$, respectively, to obtain $\operatorname{rank} B_{0}=r$.

The following robustness result is given in the theorem below.

Theorem 2. Let Assumptions A1 to A3 be valid. Then the controller defined in (27) will be robust (in the sense that the boundedness of $\left\{\left\|y_{n}\right\|\right\}$ and $\left\{\left\|u_{n}\right\|\right\}$ is guaranteed for any matrices $A$ and $B$ having the elements which satisfy (4) and (5), respectively), if (17) is satisfied with

$$
q=\max _{\substack{\hat{A} \in \Xi_{A} \\ \hat{B} \in \Xi_{B}}}\left\|\hat{A}-\hat{B} B_{0}^{+} A_{0}\right\| \text {. }
$$

In this expression, $\Xi_{A}$ and $\Xi_{B}$ are the bounded sets of all matrices $\hat{A}=\left(\hat{a}^{(i j)}\right)$ and $\hat{B}=\left(\hat{b}^{(i j)}\right)$ having the elements $\hat{a}^{(i j)} \in\left[a_{\min }^{(i j)}, a_{\max }^{(i j)}\right]$ and $\hat{b}^{(i j)} \in\left[b_{\min }^{(i j)}, b_{\max }^{(i j)}\right]$, and $\|\cdot\|$ is any matrix norm (as in (18)).

Proof. Follows immediately from Theorem 1. 
The result given in Theorem 2 may be reformulated in terms of the linear programming problems similar to that in [11] as follows.

Define the variables

$$
\hat{d}^{(i j)}=\hat{a}^{(i j)}-\sum_{k=1}^{r} h_{0}^{(k j)} \hat{b}^{(i k)}, \quad i, j=1, \ldots, m,
$$

where $h_{0}^{(i j)}$ denotes the corresponding element of the fixed matrix $H_{0}=B_{0}^{+} A_{0}$. Further, $\hat{d}^{(i j)}$ is the element of $\hat{D}=\hat{A}-\hat{B} H_{0}$, and find

$$
\max \hat{d}^{(i j)} \text { and } \min \hat{d}^{(i j)}
$$

subject to the constraints

$$
a_{\min }^{(i j)} \leq \hat{a}^{(i j)} \leq a_{\max }^{(i j)}, \quad b_{\min }^{(i j)} \leq \hat{b}^{(i j)} \leq b_{\max }^{(i j)}
$$

for each $1 \leq i \leq m, 1 \leq j \leq m$.

Since (29) describes the functions depending linearly on the variables $\hat{a}^{(i j)}$ and $\hat{b}^{(i 1)}, \ldots, \hat{b}^{(i r)}$ that are the elements of the $i$ th row of $\hat{B}$, and (31) represent the simple linear constraints, the problems given by (30), (31) are the simplest linear programming problems. They are solved independently for each pair $(i, j)$ taking into account that each element of the $j$ th column of $\hat{D}$ depends only on the elements of each $i$ th row of $\hat{A}$ and $\hat{B}$ but not on the elements of other their rows with numbers $k=1, \ldots, m, \quad k \neq i$. Then the following results can be shown to be valid.

Theorem 3. Subject to Assumptions A1 to A3, if

$$
\sum_{i=1}^{m} \max \left\{\left|\min \hat{d}^{(i j)}\right|,\left|\max \hat{d}^{(i j)}\right|\right\}<1 \quad \forall j=1, \ldots, m
$$

with $\min \hat{d}^{(i j)}$ and $\max \hat{d}^{(i j)}$ giving the solutions to the linear programming problem (30), (31), then the controller (27) applied to the system (1) guarantees that the boundedness properties (10) will be achieved in the presence of interval uncertainties defined by (4), (5).

Proof. Follows the lines of the proof of Corollary to Theorem 2 given in [11]. Due to space limitation, the details are omitted.

Thus, Theorem 3 specifies the sufficient conditions under which the pseudoinverse model-based controller (27) employed to regulating the uncertain system (1), (4), (5) will be robustly stable. It gives an effective solution to Problem 3 using a simple computation technique.

Example 2. Let the system to be controlled be described by

$$
A=\left(\begin{array}{rrr}
-0.20 & -0.15 & -0.15 \\
-0.10 & -0.25 & -0.10 \\
-0.15 & -0.15 & -0.16
\end{array}\right), \quad \text { and } B=\left(\begin{array}{rr}
1.2 & 0.1 \\
-0.6 & 0.9 \\
0.6 & 2.1
\end{array}\right) \text {. }
$$


Assuming that the parameter uncertainty is given as $a^{(11)} \in[-0.28,0]$, $a^{(12)} \in[-0.2,-0.1], a^{(13)} \in[-0.12,0], a^{(21)} \in[-0.12,0], a^{(22)} \in[-0.28,0]$, $a^{(23)} \in[-0.2,-0], a^{(31)} \in[-0.2,0], a^{(32)} \in[-0.2,-0.1], a^{(33)} \in[-0.2,-0]$, $b^{(11)} \in[0.6,1.2], b^{(12)} \in[0,0.2], b^{(21)} \in[-0.7,0], b^{(22)} \in[0.8,1.1]$, $b^{(31)} \in[0.5,1.2], b^{(32)} \in[1.9,2.2]$,

the matrices

$$
A_{0}=\left(\begin{array}{lll}
-0.25 & -0.10 & -0.10 \\
-0.15 & -0.10 & -0.17 \\
-0.10 & -0.15 & -0.19
\end{array}\right) \text { and } B_{0}=\left(\begin{array}{rr}
0.8 & 0.2 \\
-0.5 & 1.0 \\
1.0 & 2.0
\end{array}\right)
$$

yielding (by the formula $B^{+}=\left(B^{\mathrm{T}} B\right)^{-1} B^{\mathrm{T}}$ given in Remark 2)

$$
B_{0}^{+}=\frac{1}{677}\left(\begin{array}{ccc}
370 & -418 & 172 \\
-95 & 272 & 212
\end{array}\right)
$$

may be chosen to satisfy $A_{0} \in \Xi_{A}$ and $B_{0} \in \Xi_{B}$. Utilizing now Theorem 3 one can conclude that the value of $q$ determined by (28) via solving the linear-programming problem is equal to 0.87 . This shows that the requirement (17) is satisfied.

\section{SIMULATION}

To support the theoretic study, three simulation experiments were conducted. In first simulation experiment, the unstable open-loop control system with $A$ and $B$ given in Example 1 was studied. Its behavior is illustrated in Fig. 1, where $u_{n}^{(1)} \equiv 0.1$, and $u_{n}^{(2)} \equiv 0.1$ were chosen.

The second simulation of the optimal closed-loop control system containing the plant (1) and the controller (14) in the presence of the i.i.d. pseudorandom $v_{n}^{(i)} \in[-1,1]$ was conducted. The simulation results for different $y^{0} \mathrm{~s}$ with the components determined as $y^{0(1)}=7, y^{0(2)}=3, y^{0(3)}=15$ at $1 \leq n \leq 40$; $y^{0(1)}=2, \quad y^{0(2)}=7, \quad y^{0(3)}=3$ at $41 \leq n \leq 60 ; \quad y^{0(1)}=3, \quad y^{0(2)}=7, \quad y^{0(3)}=9$ at $61 \leq n \leq 100$ are presented in Fig. 2 .

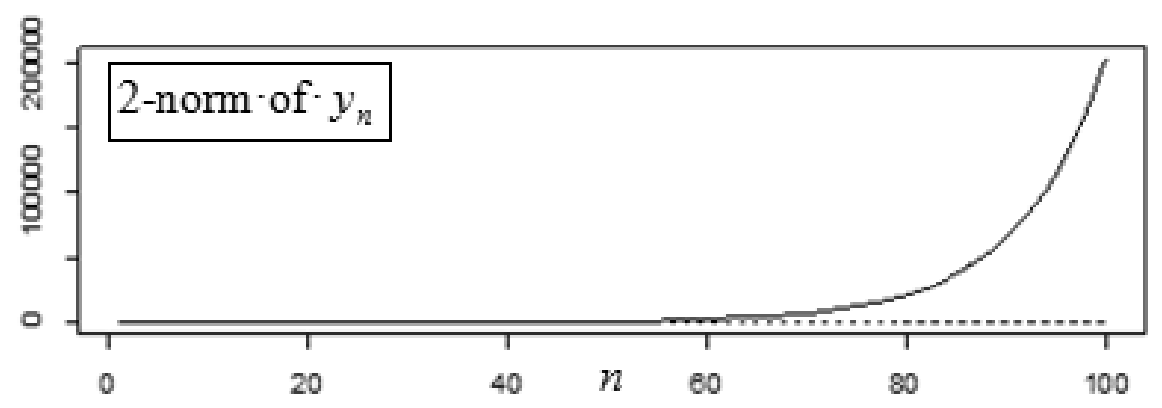

Fig. 1. 2-norm of output vector of the open-loop control system releted to Example 1 

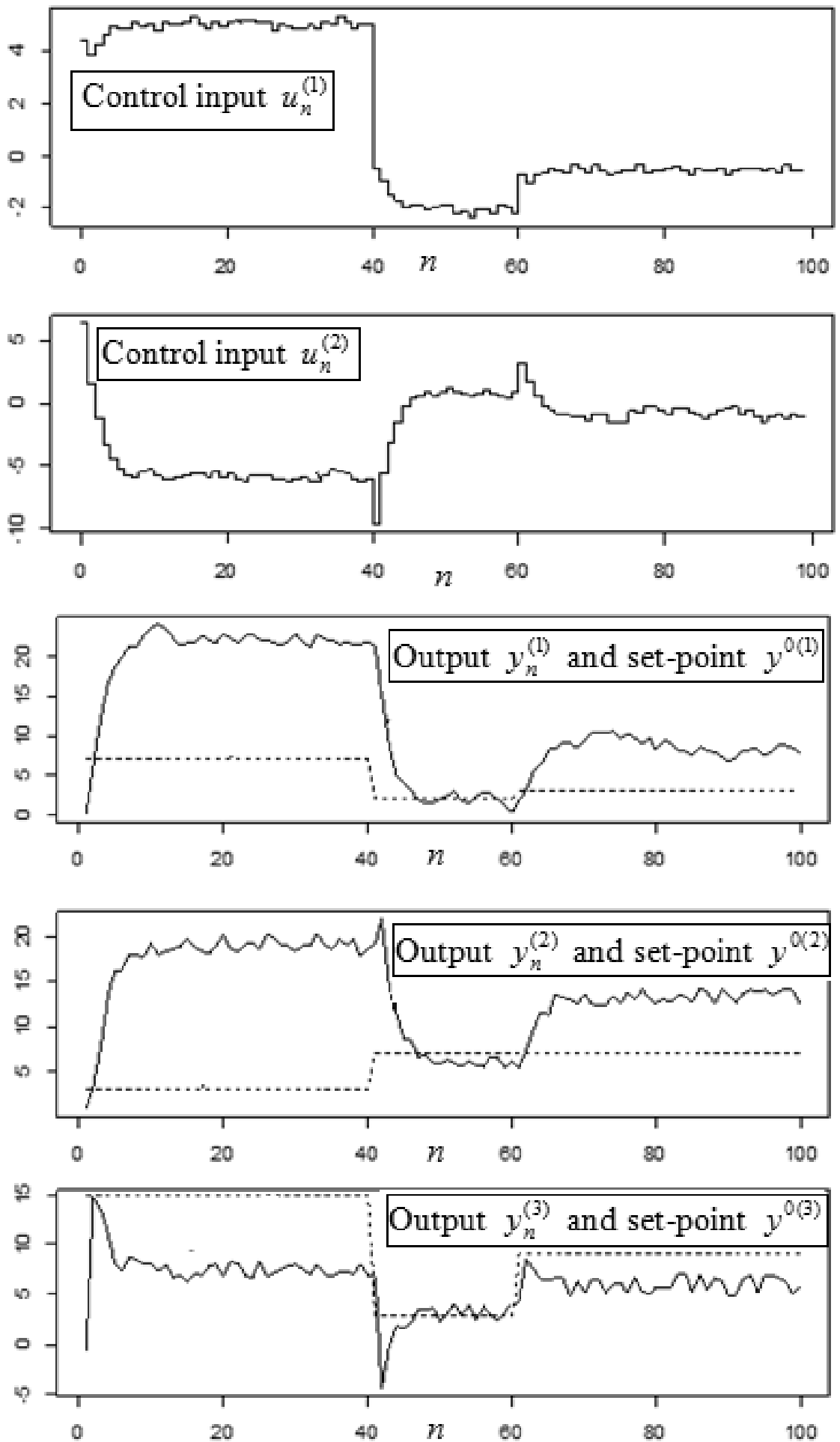

Fig. 2. Control inputs and outputs (solid lines), and set-points (dashed lines) of the closed-loop control system in the conditions of Example 1 
In the third simulation experiment, the robust closed-loop control system with the uncertainties and with the feedback described in Example 2 subject to the same disturbances and $y^{0(1)}=3, y^{0(2)}=7, y^{0(3)}=9$ was simulated. Fig. 3 depicts its results. They show that the closed-loop control system (1), (14) is stable and its performance is satisfactory enough.
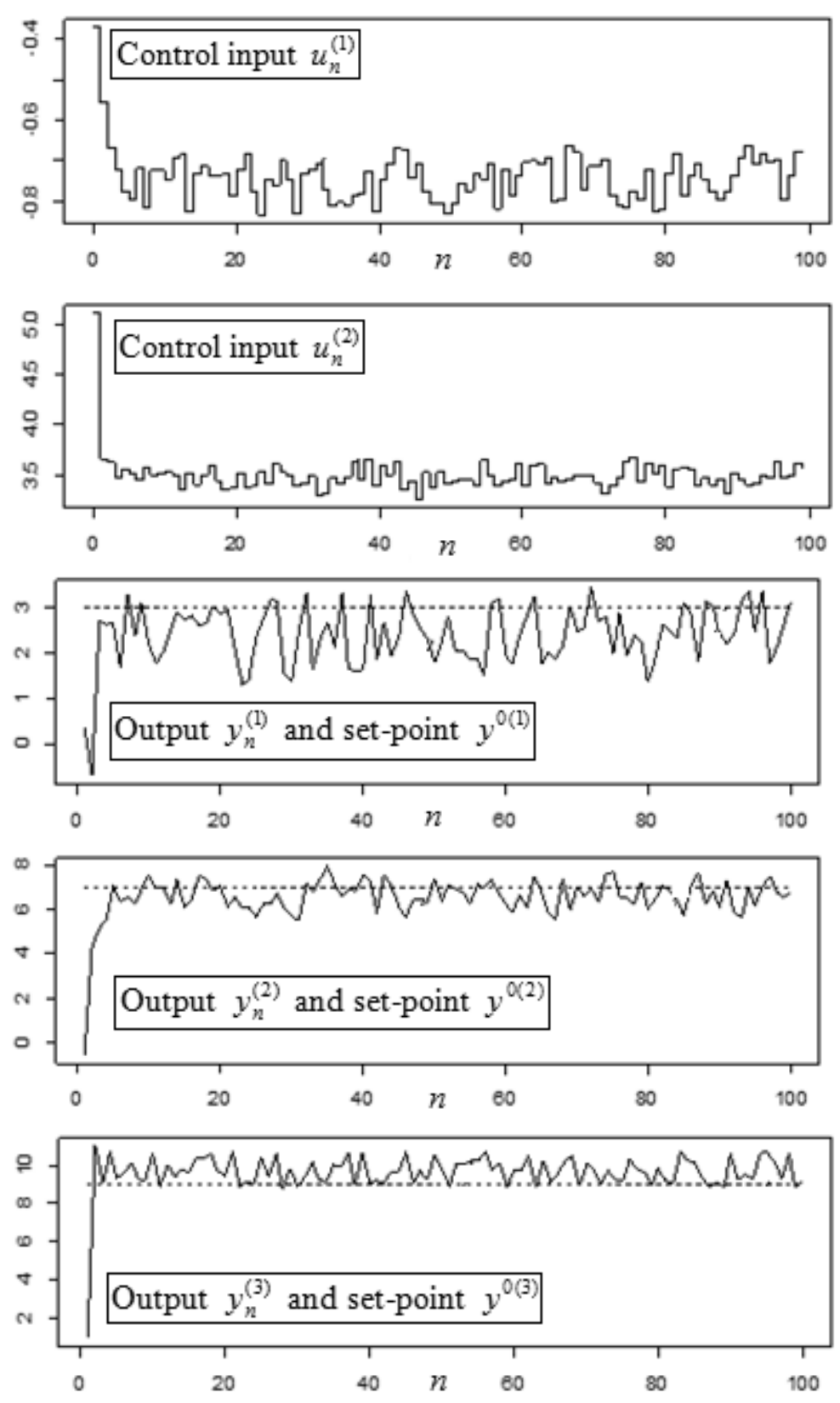

Fig. 3. Control inputs and outputs (solid lines), and set-points (dashed lines) of the closed-loop control system in the conditions of Example 2 


\section{A DISCUSSION}

To compare the pseudoinverse model-based approach proposed above with existing ones related to the SOF concept, rewrite first the control law (14) as

$$
u_{n}=L_{\mathrm{FF}} y_{n+1}^{0}-L_{\mathrm{FB}} y_{n},
$$

selecting the feedforward and feedback terms with gain matrices $L_{\mathrm{FF}}=B^{+}$and $L_{\mathrm{FB}}=B^{+} A$.

Now, consider the open-loop discrete-time system described by the standard state-space model

$$
\left\{\begin{array}{l}
x_{n+1}=A x_{n}+B u_{n}+\Gamma v_{n+1}, \\
y_{n}=C x_{n},
\end{array}\right.
$$

where $u_{n} \in \mathbf{R}^{r}, y_{n} \in \mathbf{R}^{m}, v_{n} \in \mathbf{R}^{m}$ (as before), and $x_{n} \in \mathbf{R}^{p}$ is the state vector. $A \in \mathbf{R}^{p \times p}, B \in \mathbf{R}^{p \times r}, \Gamma \in \mathbf{R}^{p \times m}$ and $C \in \mathbf{R}^{m \times p}$ are constant matrices. It is not hard to see that this system reduces to (1) by setting $C=I_{m}, \Gamma=I_{m}(p=m)$.

$$
\operatorname{det}\left(G C A^{-1} B\right) \neq 0 \text {. }
$$

Furthermore, it follows from Theorem 5 of [16] that if (34) together with some other assumptions hold, and $A$ is nonsingular then the SOF control

with

$$
u_{n}=-L_{\mathrm{FB}} y_{n}
$$

$$
L_{\mathrm{FB}}=\left(G C A^{-1} B\right)^{-1} G
$$

stabilizes the system (33) at $y_{n}^{0}=[\underbrace{0, \ldots, 0}_{m}]^{T}$ and minimizes the quadratic criterion

$$
J=\sum_{n=0}^{\infty} y_{n}^{\mathrm{T}}\left(A^{-1}\right)^{\mathrm{T}} G^{\mathrm{T}} G A^{-1} y_{n},
$$

but not the criterion (8). On the other hand, it can easily be shown that if $\operatorname{det} A \neq 0$ and (26) holds $\left(C=I_{m}\right)$ then $G$ may be chosen as $G=\beta B^{+} A$ with an arbitrary $\beta>0$ to satisfy the requirement (34). According to (36) such a choice of $G$ yielding directly $L_{\mathrm{FB}}=B^{+} A$ gives that in this case, the SOF control (35) becomes finally the pseudoinverse stabilization control having the form (32) in which $\left\|y_{n}^{0}\right\| \equiv 0$.

It is interesting to note that, contrary to [16], the pseoduinverse control (32) may be used to minimize the criterion (8) when $A$ is singular and $B$ has nonfull rank (Example 1). Nevertheless, the condition $\left\|\left(I_{m}-B B^{+}\right) A\right\|<1$ guaranteeing the ultimate boundedness of $\left\{\left\|y_{n}\right\|\right\}$ and $\left\{\left\|u_{n}\right\|\right\}$ is assumed to be satisfied (in accordance with Theorem 1 given in [16]). Of course, this condition may not be satisfied if $A$ is not the Schur stable. 
In order to cope with the instability of (1), at least, the two ways may be proposed. First, if rank $B=r$, then some $r$ outputs $y_{n}^{\left(i_{1}\right)}, \ldots, y_{n}^{\left(i_{r}\right)}$ might be included in the feedback loop to control the system (1) via an inverse model-based controller similar to (11) with the square submatrix $B\left[i_{1}, \ldots, i_{r} \mid 1, \ldots, r\right]$ (instead of $B$ ). It can be clarified that remaining outputs will become bounded if and only if all the $m-r$ diagonal elements of $A$ defined as $a^{\left(i_{k} i_{k}\right)}$ with $i_{k} \neq i_{1}, \ldots, i_{r}$ satisfy $\left|a^{\left(i_{k} i_{k}\right)}\right|<1$. Again, this way does not minimize the criterion (8). Second, we may attempt to design the SOF controller based on the ideas of $[16,19]$ et al. However, such way leads to minimization of the criterion similar to (37) but not to (8) whereas one seems to be more suitable for practical applications dealing with the problems of the nonzero set-point regulation.

Since most the process control systems remaining stable in their nature and can be described by model similar to (1) [8], we conclude that the approach proposed here has advantage in comparison with existing ones if the multivariable systems to be controlled are nonsquare and stable.

\section{CONCIUSIONS}

The paper shed some light on the existence of the pseudoinverse static output feedback controllers which can either be optimal (in the absence of any uncertainty) or be robust stable against parameter uncertainties dealing with the linear multivariable first-order discrete-time system in a hard case when its gain matrix is nonsquare (in contrast to the known results).

\section{REFERENCES}

1. Maciejowski J. M. Multivariable Feedback Design. Wokinghan: Addison-Wesley, 1989, 490 p.

2. Skogestad S., Postlethwaite I. Multivariable Feedback Control. UK, Chichester: Wiley, 1996, $592 \mathrm{p}$.

3. Glad T., Ljung L. Control Theory: Multivariable and Nonlinear Methods. New York: Taylor \& Francis, 2000, $482 \mathrm{p}$.

4. Albertos P., Sala A. Multivariable Control Systems: an Engineering Approach. London: Springer, 2006, $340 \mathrm{p}$.

5. Tan L. A Generalized Framework of Linear Multivariable Control. Oxford: Elsevie, 2017, $322 \mathrm{p}$.

6. Liu C., Peng H. Inverse-dynamics based state and disturbance observers for linear timeinvariant systems. ASME J. of Dyn. Syst., Meas. and Control. 2002, Vol. 124, No 5, pp. 376-381.

7. Lyubchyk L. M. Disturbance rejection in linear discrete multivariable systems: inverse model approach. Proc. 18th IFAC World Congress (28 Aug - 2 Sep, 2011, Milano, Italy). Milano, 2011, pp. 7921-7926.

8. Skogestad S., Morari M., Doyle J. Robust control of ill-conditioned plants: high purity distillation. IEEE Trans. Autom. Contr. 1988, Vol. 33, No 12, pp. 1092-1105.

9. McInnis B.C., Cheng J.K., Guo Z.W., Lu P.C., Wang, J.C. Adaptive control system for the total artificial heart. Proc. 9th IFAC World Congress (2-6 Jul, 1984, Budapest, Hungary). Budapest, 1984, pp. 3051-3055.

10. Zhiteckii L. S., Azarskov V. N., Solovchuk K. Yu., Sushchenko O. A. Discrete-time robust steady-state control of nonlinear multivariable systems: a unified approach. Proc. 19th IFAC World Congress (24-29 Aug, 2014, Cape Town, South Africa). Cape Town, 2014, pp. 8140-8145. 
11. Zhitetskii L. S., Skurikhin V. I., Solovchuk K. Yu. Stabilization of a nonlinear multivariable discrete-time time-invariant plant with uncertainty on a linear pseudoinverse model. Journal of Computer and Systems Sciences International. 2017, Vol. 56, No. 5, pp. $759-773$.

12. Zhiteckii L. S., Solovchuk K. Yu. Pseudoinversion in the problems of robust stabilizing multivariable discrete-time control systems of linear and nonlinear static objects under bounded disturbances. Journal of Automation and Information Sciences. 2017, Vol. 49, No. 5, pp. 35-48.

13. Iwasaki T., Skelton R.E., Geromel J.C. Linear quadratic suboptimal control with static output feedback. Systems \& Control Letters. 1994, Vol. 23, No 6, pp. 421-430.

14. Kucera V., de Souza C.E. A necessary and sufficient conditions for output feedback stabilizability. Automatica. 1995, No. 31, pp. 1357-1359.

15. Syrmos V.L., Abdallah C.T., Dorato P., Grigoriadis K. Static output feedback - A survey. Automatica. 1997, Vol. 33, No 2, pp. 125-137.

16. Garsia G., Pradin B., Zeng F. Stabilization of discrete time linear systems by static output feedback. IEEE Trans. Autom. Contr. 2001, Vol. 46, No 12, pp. 1954-1958.

17. Rosinova D, Vesely V, Kucera V. A necessary and sufficient condition for static output feedback stabilizability of linear discrete-time systems. Kybernetika. 2003, Vol. 39, No 4, pp. 447-459.

18. Mehdi D., Boukas E.K., Bachelier O. Static output feedback design for uncertain linear discrete time systems. IMA Journal of Mathematical Control and Information. 2004, No.21, pp. 1-13.

19. Bara G. I., Boutayeb M. Static output feedback stabilization with $\mathrm{H}_{\infty}$ performance for linear discrete-time systems. IEEE Trans. Autom. Contr. 2005, Vol. 50, No 2, pp. 250-254.

20. Gershon E., Shaked U. Static $\mathrm{H}_{2}$ and $\mathrm{H}_{\infty}$ output-feedback of discrete-time LTI systems with state multiplicative noise. Systems \& Control Letters. 2006, No. 55, pp. 232-239.

21. Dong J., Yang G-H. Robust static output feedback control for linear discrete-time systemswith time-varying uncertainties. Systems \& Control Letters. 2008, No. 57, pp. $123-131$.

22. Arzelier D., Gryazina E. N., Peaucelle D., Polyak, B. T. Mixed LMI/randomized methods for static output feedback control design. Proc. American Control Conference (30 Jun - 2 Jul, 2010, Baltimore, MD, USA). Baltimore, 2010, pp. 4683-4688.

23. Albert A. Regression and the Moore-Penrose Pseudoinverse. New York: Academic Press, 1972, $179 \mathrm{p}$.

Received 10.03.2020 
Л.С. Житецькийㄱ, канд. техн. наук,

в.о. зав. відд. інтелектуальних автоматичних систем

e-mail: leonid zhiteckii@i.ua

B.M. Азарсков ${ }^{2}$, д-р техн. наук, професор,

зав. каф. аерокосмічних систем керування

e-mail: azarskov@nau.edu.ua

O.A. Сущенко ${ }^{2}$, д-р техн. наук, професор,

проф. каф. аерокосмічних систем керування

e-mail: sushoa@ukr.net

Ф.Й. Яновськийㄹ, д-р техн. наук, професор,

зав. каф. електроніки, робототехніки

і технологій моніторингу та інтернету речей

e-mail: yanovsky@nau.edu.ua

К.Ю. Соловчук

ст. викл. каф. вищої та прикладної математики,

e-mail: solovchuk_ok@ukr.net

${ }^{1}$ Міжнародний науково-навчальний центр інформаційних

технологій та систем НАН України і МОН України,

пр. Акад. Глушкова, 40, м. Київ, 03187, Україна

${ }^{2}$ Національний авіаційний університет,

пр. Любомира Гузара, 1, м. Київ, 03680, Україна

${ }^{3}$ Національний університет «Полтавська політехніка імені Юрія Кондратюка», пр. Першотравневий, 24, м. Полтава, 36011, Україна

\section{КЕРУВАННЯ БАГАТОВИМІРНИМИ СИСТЕМАМИ З ПРЯМОКУТНИМИ МАТРИЦЯМИ КОЕФІЦІСНТІВ ПІДСИЛЕННЯ НА ОСНОВІ ПСЕВДООБЕРНЕНОГО СТАТИЧНОГО ЗВОРОТНОГО ЗВ'ЯЗКУ}

Вступ. Стаття стосується регулювання на ненульовому заданому рівні лінійної дискретної багатовимірної системи першого порядку. Розглядається випадок, коли кількість вихідних змінних перевищує кількість каналів передачі керувальних дій. Припускається, що наявними $є$ довільні, але обмежені невимірювані збурення. Вважається, що елементи матриць, які фігурують у рівнянні системи, невідомі, однак апріорі відомими є їхні межі. 3 практичної точки зору важливо розробити простий регулятор, подібний до регулятора типу SOF (static output feedback). Труднощі, пов'язані з цим завданням, полягають у встановленні умов існування регулятора типу SOF, здатного справитися з такою системою. Поставлено та розв'язано три різні завдання, а саме: забезпечення оптимальності, граничної обмеженості та робастності замкненої системи керування.

Мета роботи - дати відповідь на запитання: чи існує регулятор типу SOF, в основу якого покладено концепцію псевдообернення, аби стабілізувати деяку багатовимірну систему першого порядку з прямокутною матрицею коефіцієнтів підсилення?

Методи. Використовуються методи, основані на теорії матриць.

Результати. Аби придушити невимірювальні збурення, запропоновано керування, яке базується на методі псевдооберненої моделі. Цей метод формально приводить до реалізації статичного зворотного зв'язку. Встановлено умови оптимальності та робастності такого регулятора. Для підтвердження теоретичного дослідження наведено числові приклади та результати моделювання.

Висновок. Стаття проливає деяке світло на існування псевдообернених регуляторів, що реалізують статичний зворотний зв'язок, які можуть бути або оптимальними (за відсутності будь-якої невизначеності), або робастно стійкими до невизначеності відносно параметрів лінійної багатовимірної дискретної системи першого порядку у випадку, коли іiі матриця коефіцієнтів підсилення $є$ прямокутною (на відміну від відомих результатів).

Ключові слова: дискретний час, методи керування зі зворотним зв'язком, псевдообернення, багатовимірні системи керування, робастність. 